\title{
Important and achieved competence for Swedish vocational teachers: A survey with teachers and principals
}

\author{
Sofia Antera, Marianne Teräs, \\ Staffan Nilsson \& Helena Rehn
}

Stockholm University, Sweden (sofia.antera@edu.su.se)

\begin{abstract}
Vocational teachers have a key role in the professional growth of vocational students, making their competence an important factor in the quality of VET. This study explores how principals and vocational teachers identify important and achieved competencies in relation to vocational teachers' work. The data was collected through an online questionnaire, centred in two types of competence, competence important for teachers (important competence) and competence they consider they have already developed (achieved competence). For each type, a set of 27 competencies was evaluated on a Likert-scale by 370 participants, including both teachers and principals. The statistical analysis was primarily descriptive. The findings indicated that good communication with students, assessment of students' knowledge, skills and abilities, and creating conditions for learning, are the three most important and achieved competencies in VET teachers' work. On the contrary, previous teaching experience, working experience with adults and migrants, and the competence related to recruitment of students and marketing of the school, were seen as the least important and achieved ones. Different actors, meaning principals and teachers, reached an agreement on these findings. Future research should look into the reasons behind the selection of specific competence as important and the processes of competence development.
\end{abstract}

Keywords: vocational teachers, competence, quantitative research, Sweden, teaching competence 


\section{Introduction}

Modern workplaces change with unprecedented speed, bringing new challenges for vocational education and training (VET). With VET given the duty of preparing skilled workers and high-level expertise, today's vocational teachers have a crucial role to play in the professional growth of future workers (Asghari, 2018; Mårtensson et al., 2019; Wenström et al., 2018). In 2018, 48.4\% of the students in upper secondary education in Europe (EU-27) learned a considerable part of their vocational competence by attending a vocational programme and with the support of vocational teachers (Eurostat, 2020). Nevertheless, the status of vocational teachers is influenced by the low status of VET (Cedefop, 2020), harming the image of vocational teachers and lowering the attraction of potential teachers to the profession (Grollman, 2009).

In Sweden, new competencies have also become relevant in the education arena of vocational teachers, which consists of public and private schools that work under the general New Public Management (NPM) approach. Alexiadou and Lundahl (2016) pointed out that the work of principals has become that of a business leader including planning, evaluation and budgeting and the school has adopted business characteristics in its function. Under this new organisation, schools have to compete over student recruitment, introducing client relationships between teachers and their students (Evetts, 2014). In addition to these demands, the growing importance of vocational teachers to have connections with the industry, in order to keep their knowledge updated has been stressed (Andersson \& Köpsén, 2019; Confederation of Swedish Enterprise [CSE], 2020; Mårtensson et al., 2019).

The change in competence demands is accompanied by the ageing profile of vocational teachers. The issue of vocational teachers' shortage in Sweden is expected to increase in the coming decades. To reach the demand of the profession by 2031, 1130 teachers should be trained per year. At the same time, vocational teacher training does not attract those numbers of students, with the number of study places exceeding the number of graduates during the academic years 14/15-16/17 (CSE, 2020; National Agency of Education [NAE], 2014; NAE, ReferNet Sweden, 2019). Nevertheless, it is worth mentioning that the shortage is not equally distributed; the Electricity and energy and the Industrial technology are programmes identified with the bigger teacher shortage (Asghari \& Berglund, 2020). Hence, the challenge is not only to attract potential vocational teachers, but that they should also have a specific vocational profile.

Due to this shortage, the profession of vocational teachers in Sweden has become less regulated leaving the school principals with the responsibility of deciding if a teacher is competent, when there is a lack of qualified candidates. In this context of NPM, fewer vocational teachers joining the profession combined with the fact that some of them are unqualified in the teaching profession creates 
a gap in the education process that is filled by individuals, whose teaching competence remains unknown (NAE, 2020e).

Improving the standing of vocational teachers can increase both the image and the quality of VET (Grollman, 2009). However, since teachers' competence is not always developed in formal learning settings, there is a need to explore it further, whether is gained through institutionalised education or workplace learning. This study explores vocational teacher competence, aiming not only at teaching competence, but also at vocational and general competence, as well as competence connected to the workplace and the teachers' task in building partnerships with industry (Manley \& Zinser, 2012; Sartori et al., 2015).

\section{Aims and research questions}

The overall aim of the study is to describe and explore how principals and vocational teachers perceive the competence/s of vocational teachers. Specifically, the study seeks to compare how teachers and principals identify important and achieved competencies in relation to the challenges encountered at the workplace. The research questions are the following:

- What do vocational teachers and principals identify as important and achieved competence for vocational teachers?

- How do vocational teachers' and principals' perceptions of important and achieved competence differ?

- What challenges do vocational teachers identify in their work?

Aiming for clarity, some core concepts need to be explained at this point. Vocational teachers refers to teachers employed to teach vocational subjects. In the present study the level is upper secondary and adult education. Workplace in this study refers to the workplace of the vocational teachers. Therefore, workplace is any education institution that vocational teachers are employed in. Finally, competence has a developmental, situated and dynamic nature (Antera, 2021). It entails knowledge, skills, attitudes and values and it address the individual's capacity to actualise a specific activity in a given situation and context. Competency is a smaller part of a generic competence, and it refers to an ability to perform a very specific task (Mulder, 2014).

\section{Swedish vocational teachers}

In 2019/20, 6,750 vocational teachers were employed in upper secondary education in Sweden. In addition, 1,121 were part of adult education (NAE, 2020a, 2020c). For upper secondary education the amount of qualified vocational teachers reached $57.1 \%$ (NAE, 2020a), whereas for adult education, the respective per- 
centage was $66.7 \%$ (NAE, 2020c). The population of vocational teachers employed in upper secondary level is described as older than general subject teachers, with a higher percentage of part time employment and higher dropout rates. Moreover, vocational teachers begin working in education at an average age of 40 , while the average age for vocational teachers is 49 (NAE, 2014). A number of teacher positions are also filled with qualified vocational teachers, who still might teach courses that are not within the vocational subjects they are formally qualified for.

Despite the relative high percentages of non-qualified teachers, vocational teacher training is offered by ten higher education institutions in Sweden ${ }^{1}$. The programme consists of 90 ECTS (60 ECTS in courses and 30 ECTS in work placement). The entry requirements include validation of vocational skills and previous working experience. Each case is evaluated independently, as there is a wide variation of qualifications as well as many differences between different occupations (Asghari \& Berglund, 2020; Stockholm University, 2020b).

Due to the increasing shortage of vocational teachers qualified in teaching, individuals are allowed to become employed in vocational subjects, as long as there is no other applicant qualified for the position and the non-qualified applicant is judged as competent and suitable by the employer (NAE, 2020e). This category of vocational teachers has the possibility of becoming qualified in teaching by reading a shortened vocational teacher education of 60 ECTS, since they are credited with 30 ECTS through their professional experience as teachers.

Vocational teacher training programmes provided by universities offer no specialisation in any course. They instead teach the general approach in relation to the profession of teaching and more specifically vocational teaching (Asghari \& Berglund, 2020). The exception is Stockholm University which offers two tracks in the vocational teacher training, one for health care professionals and one for the rest. Most of the programmes are offered part-time and distance, allowing many of the students to work and study in parallel (CSE, 2020).

\section{Vocational teachers' competence in previous research}

Previous research on vocational teachers' competence has focused on several themes, including pedagogical and didactical competence (Tutlys et al., 2019), digital skills (Harju et al., 2020), subject knowledge and subject pedagogy (Raudasoja \& Kaitala, 2019) and finally the continuous professional development of vocational teachers, discussed by Bound (2011) and Andersson et al. (2018). Teräs et al. (2019) investigated a set of skills as perceived by vocational student teachers at Stockholm University, and found that the skill of global connections was the least appreciated as well as the least applied skill in teaching. 
Fejes and Köpsén (2014) discussed identity formation for vocational teachers, stressing the lack of strict requirements for vocational teacher training, and highlighting how this affects their preparedness to teach. Their semi-structured interviews drew the attention to the formation of identities through boundary crossing, from the prior occupation's community of practice, to the teaching occupation community of practice. Findings, including that many vocational teachers do not have up-to-date vocational identities, supported that teachers who can balance their participation in both communities tend to be more prepared for teaching. Köpsén and Andersson (2018) delved deeper into the boundary crossing processes of vocational teachers, showing how such activities enable their continuing professional development and support their development. Finally, Asghari (2018) pointed out a relationship between the professional competence that vocational teachers develop themselves and their expectations for competence development from their students, highlighting the crucial role teachers have in the learning process.

Approaching vocational teachers' work through boundary crossing between school and workplace, vocational teachers have a double identity, being both craftsmen and teachers (Fejes \& Köpsén, 2014; Nylund \& Gudmundson, 2017). Nylund and Gudmundson (2017) have shown that vocational teachers usually identify more either with their teacher or their craftsman identity, with this identification having an impact on what is regarded as important knowledge for them. In other words, the teacher prioritises teaching competence as important part of the work, whereas the craftsman sets more emphasis on the occupation related competence and the vocational knowledge and culture. Focusing on vocational teachers' relational work with work-based learning for students, Mårtensson et al. (2019) revealed the three roles of vocational teachers while coordinating the process. Whether they perform their role as recruiters, matchmakers or firefighters, vocational teachers should have a good relationship and a productive integration with students to deliver quality apprenticeship planning.

This need for constantly updated vocational knowledge combined with teaching skills, and awareness of several aspects of the industry currency is pointed out as important by international research as well. Manley and Zinser's study (2012, p. 496) concluded that 'keep up-to-date professionally; provide for student safety; assess student performance and skills; evaluate instructional effectiveness; and direct students in applying problem-solving techniques' are the most important competencies for vocational teachers in the United States. Placing the focus on viewing what competencies teachers consider important in their work, Sartori, Tacconi and Caputo (2015) addressed the training needs of vocational teachers in Veneto, Italy. The findings indicated that teachers already had the necessary skills to perform their work, as the ratings on self-assessment were 
higher than importance. Nevertheless, during focus groups, the teachers declared lack of skills and need for further development, expressing a preference for short courses, which would be tailored to their needs.

\section{The principal's role}

The Education Act (Swedish Parliament, 2010) introduced a teacher certification, adding a required tertiary teaching degree, and regulating the content and educational level the teacher was qualified to teach. A teacher certification became a requirement for employment in the education field introducing formal qualifications for those involved in teaching activities. The certification process is conducted by the National Agency for Education.

Nevertheless, because of the lack of qualified teachers, VET teachers are exempted from the requirements by law. If a non-qualified or non-certified VET teacher is or becomes permanently employed, as an exception, he or she is exempt from the requirements and is allowed to both teach and assess the students. This alternation of the legislation gives principals considerable authority over selecting competent teachers. The responsibility of reassuring quality is moved from a certification process, with formal knowledge validation, to the individual judgement of principals. In that sense, their opinion seems to have a role to play in the competence profile of vocational teachers. Moving the dependency of civil servants from the common professional standards to local management has been discussed as deprofessionalization of civil servants as resulted from NPM (Jarl et al., 2012).

School principals in Sweden are required to have an academic education. This education is not necessarily within the field of pedagogy. However, $87 \%$ of school principals hold a university degree in pedagogy (NAE, 2021b). School principals are responsible for ensuring the overall students achievement, involving parents and the local community in the school life, but also reassuring quality teaching (Norberg, 2019). Principals' responsibilities include primarily budgeting, planning and managing the school personnel (Swedish Confederation of Professional Associations [SACO], 2021). Their overall role is both of a manager and a leader of an education institution.

In NAE's report (2014), principals were surveyed with regards to the criteria they use when employing vocational teachers. The results have shown that teaching competence is not prioritised. However, the focus is on vocational knowledge and previous working experience on the subject the vocational teachers would teach. Remaining connections with the working life is the next most important competence, according to the report, considered to be absolutely necessary as the first one too. Vocational teacher training and experience of working with young people is generally considered less necessary, and thus not a requirement for recruitment. Antera's research (2020) on municipal and popular adult education 
supports these findings, with vocational knowledge and experience coming first, followed by teamwork and then teaching experience or competence.

Therefore, it seems that the low amount of qualified teachers is not seen as the biggest supply issue from the principals' perspective, who appear to focus on competence like occupational experience and labour market contact (NAE, 2014).

\section{Methods}

Adopting a quantitative approach, this study aims to identify important and achieved competence for vocational teachers. The literature and the collection of statistical information about vocational teachers' competence in Sweden is limited (Fejes \& Köpsén, 2014) and fragmented, leaving a gap, and hindering the drawing of the competence profile for Swedish vocational teachers. While some information can be found about secondary vocational teachers, for those who work in adult vocational education the picture is even more blurry. A quantitative approach aspires to bring the bigger picture forward drawing the competence profile of vocational teachers in Sweden, not as a definite result, but as a starting point for further exploration.

The research design is cross-sectional, collecting data in large amounts from teachers and principals through an online questionnaire (Cohen et al., 2011). The study design incorporates some comparable aspects, as well as both the items and the groups in the sample population are selected to allow comparisons, between and within subjects (Field, 2009). This research design can facilitate more than descriptive analysis, offering multiple perspectives in approaching vocational teachers' competence and allowing some inferences that can act as indications for further research.

\section{The sample}

During the design phase of the study, there was an effort to estimate the amount of vocational schools and teachers that exist in Sweden (power analysis for sample size) (Cohen, 1988). Vocational programmes are offered in schools where general education is offered. Unfortunately, the statistics available regarding VET were not separated from the statistics for general education; hence the ability to identify the exact number of vocational schools and their contact details was limited (NAE, 2020d).

The sample was selected through stratification, aiming to improving precision (Salkind, 2010). The strata included upper secondary and adult education schools, as both offer upper secondary VET courses. All the secondary schools that had more than ten vocational students in 2019/20 were contacted (759). All schools in adult education (390) were contacted, since it was not possible to know which ones of them offer vocational education. The database with the school information and contact details was provided by NAE (2020d). 
The researcher team decided to reach teachers through contacting their schools, as that would offer the possibility of a more randomised sample. On the contrary, channels where teachers are active, like social media or unions, would have influenced the quality of the data towards specific directions. An information email with link to the questionnaire was sent to the general school address, requesting that the email should reach the principal. The email included a survey that was to be filled in by principals and be forwarded to teachers.

The email addresses of many schools were not updated and there is a possibility that the questionnaire has not reached all the recipients. The survey was open from 08/10/2020 until 27/10/2020 and received 370 answers. One reminder was sent in 18/10/2020.

The sample for this study consisted of 370 people, 280 vocational teachers and 90 school principals. The participants' age ranged from 26 to 74 with a mean of 49.7 years of age $(\mathrm{SD}=9.9) .33 \%$ of the sample had graduated from higher vocational education (Yrkeshögskola) and the largest percentage of them were qualified teachers, with $31.4 \%$ for teachers and $20 \%$ for principals lacking teacher training. Their occupational experience ranged from 0 to 40 years with a mean of $16.8(\mathrm{SD}=9)$ and their teaching experience reached a mean of 10.3 years $(\mathrm{SD}=8.1)$. Nearly $70 \%$ of the participants had a fixed contract and worked full time, with 268 of them employed in upper secondary and the rest in adult education.

Regarding the sample group of school principals (90), 87.8\% have worked as teachers, while $80 \%$ hold a teaching degree. Moreover, $91.1 \%$ have attended or currently undergoing the principals training programme, whereas $10 \%$ have reported that their higher level of education is vocational training.

Regarding the schools' profile, they were located all over Sweden, with a higher representation of Region Västra Götaland, Eskilstuna, Stockholm, Malmö, Linköping and Sunne. Upper secondary schools had the highest representation with regards to school type, which is expected as there are more upper secondary schools than adult education centres. Finally, $71.1 \%$ of the schools were public, while the rest were publicly funded private schools (friskolor).

\section{Representativeness of the sample}

The sample was selected through stratification. The strata included upper secondary and adult education. After those strata were selected, all schools with potential participants were contacted.

The information presented on the vocational teacher population has been calculated by the first author based on the statistics by the NAE (2020a, 2020b, 2020c). These statistics present demographic details on teachers separately for upper secondary and adult education. In addition, the teachers are categorised as to the subject they teach. From this detail, their distinction from general education teachers becomes feasible. 
With reference to the strata, $24.5 \%$ of the teachers working in upper secondary education are vocational teachers, while for adult education this percentage is 25.5\% (NAE, 2020a, 2020b, 2020c). Vocational teachers are also employed in higher vocational education institutions and folk high schools, but they were not targeted in this study.

Table 1. Gender representation in population and in the sample $(n=370)$.

\begin{tabular}{lllll}
\hline School type & \multicolumn{2}{l}{ Population } & \multicolumn{3}{l}{ Sample } \\
\hline & Women & Men & Women & Men \\
\cline { 2 - 5 } High schools & $37.6 \%$ & $62.4 \%$ & $42.3 \%$ & $57.1 \%$ \\
Adult education centres & $68 \%$ & $32 \%$ & $71.4 \%$ & $26.9 \%$ \\
\hline
\end{tabular}

For upper secondary and adult education the gender representation in vocational teachers is $57.8 \%$ men and $42.2 \%$ women (NAE, 2020a, 2020b, 2020c). In the sample of this study $49.3 \%$ are men, while $50 \%$ are women. The Chi-square test of significance, $\chi^{2}(1)=15.2, p=0.00$, has shown statically significant difference, meaning that women are represented in the study slightly more than in general population (Table 1). Finally, the questionnaire allowed the option of other in the gender question, which explains the missing percentages in the sample column.

Table 2. Vocational programme representation in population and in the sample $(n=280)$.

\begin{tabular}{lcc}
\hline Vocational training programme & $\begin{array}{c}\text { Percentage in } \\
\text { population }\end{array}$ & $\begin{array}{c}\text { Percentage } \\
\text { in sample }\end{array}$ \\
\hline Children and reaction & 9 & 10.7 \\
Building and construction & 11 & 11.8 \\
Electricity and energy & 11 & 6.4 \\
Vehicle and transport & 12 & 11.1 \\
Business and administration & 7 & 8.6 \\
Handicraft programme & 6 & 3.9 \\
Hotel and tourism & 2 & 1.8 \\
Industrial technology & 7 & 7.5 \\
Agriculture (Natural resource use programme) & 10 & 11.1 \\
Restaurant management and food programme & 7 & 5.4 \\
HVAC and property maintenance programme & 3 & 2.1 \\
Health and social care & 15 & 19.6 \\
\hline Total & 100 & 100 \\
\hline
\end{tabular}

Regarding the representativeness of different vocational programmes in the sample, table 2 summarises the percentage of teachers for different vocational pro- 
grammes in upper secondary and adult education, and the respective percentages in the sample. According to Chi-square test of significance, $\chi^{2}(11)=15.7$, $p=0.150$, the representation of the vocational programmes in the sample is not significantly different than the population.

Regarding the representation of teachers without teacher training (pedagogisk högskoleexamen), they constitute $43.4 \%$ of the vocational teachers at upper secondary schools and 33.3\% at adult education schools (NAE, 2020a, 2020b, 2020c). The respective percentages in the sample are $31.9 \%\left(\chi^{2}(1)=11.1, \mathrm{p}=0.001\right)$ and $28.5 \%\left(\chi^{2}(1)=0.643, \mathrm{p}=0.423\right)$.

In conclusion, although having a clear picture of the original population is very difficult due to the lack of statistics focusing only on vocational teachers, the sample synthesis seems to resemble the population to a high extent. Its size, however, remains relatively small.

\section{The instrument}

The study is inspired from integrated occupationalism, which is based on 'notions of holistic, generic and integrated sets of knowledge, skills and attitudes, which are needed in occupational roles and situations' (Mulder, 2014, p. 129). More specifically, for the instrument construction, four competence domains were considered namely pedagogical (teaching competence), substantive (occupational competence), organisational (administration and school life competence) and developmental domain (lifelong learning) as developed in Sartori et al. (2015). These overarching aspects of teachers' competence have been operationalised according to previous research studies (Government Offices of Sweden [GOS], 2008; Manley \& Zinser, 2012; Sartori et al., 2015). Content wise items overlap in the way they represent the four competence areas. Previous frameworks lacked items regarding special students groups, which are key aspects in the Swedish VET (students with special needs, adults and migrants). Supposing that teachers might have relevant experience, which is not certified, the word experience was used instead of terms denoting ability, to not discourage reporting competence not fully developed or certified. This questionnaire collected information regarding:

- Demographics (age, gender, working experience, educational background etc.),

- questions regarding teachers' competence considered important for the job, and competence considered as achieved or developed,

- questions about challenges in the teaching practice,

- and finally, some additional questions regarding COVID 19.

The questions regarding COVID 19 were added in an effort to collect information that can be related to the sudden emergence of the pandemic. However, relevant 
results are not reported in this article. The questionnaire was in Swedish and was distributed in digital form.

The demographic data was collected with aim to draw the profile of the current vocational teachers. The main idea behind the questionnaire, though, is centred in the two set of questions about competence important for teachers and competence they have already developed (achieved competence). This allowed comparisons between important and achieved competence.

A set of 27 items was prepared, originally in English and then translated into Swedish. The participants assessed the items, from 1 to 7 , as to what degree they see them as important (importance scale) to their job and to what degree they have developed them (achievement scale). Vocational teachers assessed them referring to themselves, while principals assessed them referring to teachers. Finally, the questionnaire for principals did not include a question on challenges during teaching.

With regards to challenges, they were rated in a scale of 1 to 7 , with 7 meaning that the challenge affects teachers' job to the highest extent possible. The scale was labelled as 1 the challenge affects me to some extent, 4 to a relatively large extent and 7 to a very large extent.

The form of the questions included three Likert-scale questions and one ranking question, three open-ended questions, and demographic questions (open and closed ended).

\section{Reliability and construct validity}

In order to understand and grasp the concept of competence, the first author performed a systematic literature review focusing on the professional competence of vocational teachers (Antera, 2021). The instrument was inspired by international studies (Manley \& Zinser, 2012, Sartori et al., 2015), which had previously operationalised the concept of competence, and more specifically competencies for vocational teachers. However, changes were made to be fit for the Swedish context. These changes were informed by the literature and by reports on Swedish vocational teachers (CSE, 2020; NAE, 2014). In addition, the final version of the instrument was evaluated and agreed upon by the research team members.

The Swedish questionnaire was piloted with 14 student teachers attending the programme for vocational teacher training at Stockholm University. Cronbach's alpha for the 27-item scale of importance and the 27-item scale of achievement were 0.953 and 0.927 respectively. The challenge scale consisted of 30 items, with $\mathrm{a}=0.915$.

\section{Analysis}

For the analysis the researchers employed mostly descriptive statistics in SPSS (Statistical Package for Social Sciences). Nevertheless, the data was mostly skewed and non-parametric tests has been used. The Friedman test was used to 
calculate mean ranks, based on which competence items and challenges were ranked. Friedman's test ranks all the values given by the same subject for different items (e.g. 27-item scale of importance). The values are then replaced by ranks with rank 1 being attributed to the lowest value. The mean of the ranks for each item is then calculated.

The Mann Whitney test was used to compare two independent samples (e.g. females-males, teachers-principals), while Kruskal Wallis was applied for many independent samples (e.g. vocational programmes). Finally, the Wilcoxon signed rank test supported the comparison of two related samples, important and achieved competence (Field, 2009).

\section{Ethics}

Research in the field of vocational teachers is very limited (Fejes \& Köpsén, 2014). Vocational teachers seems to have been denied a voice as vocational teachers, while they have often been perceived as part of the general teaching population. The study recognises vocational teachers as experienced professionals, that can answer the question of what the competence demands for their work are better than researchers, and therefore sets them in the centre and asks for their opinions. A different approach would be to assess the competence of teachers by measuring their performance, through tests or observations. Instead, it is considered more beneficial for the teachers themselves to self-reflect and present their competence as they experience it.

Participation was voluntary both for vocational teachers and school principals. All potential participants were informed about the study and its aims in advance. The questionnaires were anonymous and the answers confidential. The tool used for the survey was Survey and Report, provided by Stockholm University. All personal information has been processed according to GDPR regulations (Stockholm University, 2020a) and the ethical principles for research in social sciences (Swedish Research Council, 2017).

\section{Findings}

This study aims at describing, firstly, what competencies are perceived as important to deal with the challenges encountered in the workplace and, secondly, what competencies teachers consider themselves to have achieved. In the findings, the important and achieved competence are reported and compared first, presented for both teachers and principals, as the statistical differences between them are not significant in their majority. The differences identified between teachers and principals follow. Finally, the challenges in vocational teachers' everyday work are reported. 


\section{Comparing important and achieved competence}

The ranking of the two scales offers the broader picture of how the participants evaluate professional competence. The following table presents the ranking of the competencies with reference to their importance and achievement level. The ranking is based on the mean ranks of importance (calculated with Friedman's test). Good communication with the students is the competency highest ranked by the participants. The item in the questionnaire is quite specific as it mentions communication with the students, but in general good communication is an interpersonal/social skill that can be viewed separately from the teaching profession as well (Langelotz, 2014; Pumphrey \& Slater, 2002).

Table 3. Achievement and importance level of competence $(n=370)$.

\begin{tabular}{|c|c|c|c|}
\hline & Competency & Importance & Achievement \\
\hline 1 & has good communication with the students & 20.81 & 19.61 \\
\hline 2 & can assess students' knowledge, skills and abilities & 19.68 & 17.86 \\
\hline 3 & $\begin{array}{l}\text { can create conditions for all students' learning and } \\
\text { development }\end{array}$ & 19.62 & 16.08 \\
\hline 4 & $\begin{array}{l}\text { actively work with discrimination and other abusive } \\
\text { treatment }\end{array}$ & 18.89 & 16.67 \\
\hline 5 & evaluates and develops their own teaching & 18.50 & 15.70 \\
\hline 6 & is able to plan the teaching process & 18.21 & 17.77 \\
\hline 7 & can collaborate with colleagues & 18.21 & 18.15 \\
\hline 8 & keep vocational knowledge and skills updated & 17.91 & 15.59 \\
\hline 9 & clarifies the evaluation and grading criteria for students & 17.86 & 15.53 \\
\hline 10 & collaborate with working life & 17.20 & 16.01 \\
\hline 11 & is in agreement with the school's values and aims & 16.60 & 16.42 \\
\hline 12 & has knowledge of the curriculum they teach & 16.35 & 15.88 \\
\hline 13 & participates in finding placement positions of quality & 15.10 & 15.18 \\
\hline 14 & works continuously with competence development & 14.30 & 12.63 \\
\hline 15 & has theoretical-didactical knowledge on teaching & 13.70 & 11.88 \\
\hline 16 & $\begin{array}{l}\text { is able to use information technology to design and deliver } \\
\text { learning }\end{array}$ & 13.54 & 13.80 \\
\hline 17 & has experience working with students with special needs & 12.08 & 12.47 \\
\hline 18 & has knowledge of different cultures & 11.54 & 9.75 \\
\hline 19 & has teacher training & 11.37 & 14.59 \\
\hline 20 & remains updated on pedagogical and teaching methods & 10.82 & 10.41 \\
\hline 21 & is able to incorporate aspects of sustainability in learning & 10.25 & 10.23 \\
\hline 22 & is willing to become a mentor for new teachers & 8.65 & 12.09 \\
\hline 23 & has administrative skills & 8.46 & 11.17 \\
\hline 24 & has experience of working with adults & 8.06 & 12.56 \\
\hline 25 & has previous teaching experience & 7.86 & 11.48 \\
\hline 26 & has experience of working with migrants & 6.67 & 8.71 \\
\hline 27 & can work with student recruitment and school marketing & 6.14 & 9.79 \\
\hline
\end{tabular}


The second most important competence is the assessment of students' knowledge, skills and abilities. Combined with creating conditions for learning they are among the teaching competence of every type of teacher, and their ranking in the top is well expected (Kilbrink et al., 2014). Among the last competencies in the ranking, there are the previous teaching experience, working experience with adults and migrants and the competency related to recruitment of students and marketing of the school.

An interesting finding is that with regards to student diverse population, $e x-$ perience of working with students with special needs is ranked higher both by teachers and principals, while working with migrant or adult students is ranked very low. Statistics show that the percentage of migrant students in VET in upper secondary schools is $23 \%$ for 2020/21 (students born abroad or born in Sweden with both parents born abroad) (NAE, 2021a). It is therefore, not expected that migrant related experience is not considered of higher importance.

A Wilcoxon Signed-ranks Test indicated statistically significant differences between achievement and importance for all items, with $p<0.05$. The only exception is the one regarding the working experience with migrants, which presents differences, but not statistically significant.

Comparing achieved and important competencies, there are two patterns detected. For the competencies that are higher in the ranking, the importance value is higher than the value of achievement. Towards the lower positions of the ranking, the achievement values are higher than the importance values, showing that teachers report having achieved competence that is not of high importance to their job.

Mann Whitney test $(\mathrm{N} \text { female }=192, \mathrm{~N} \text { males }=175)^{2}$ showed that female participants rated 18 items as statistically significant higher than male ones with reference to important competence. They also rated 9 items higher than male participants with reference to achieved competence. In all cases, there is a tendency from female participants to rate items higher and so, it can be assumed that they are either more confident or consider themselves more competent.

Comparing upper secondary and adult education schools, the statistical significant differences from Kruskal Wallis ${ }^{3}$ test, $\mathrm{p}<0.05$ detected refer to the following items:

- use of information technology to design and deliver learning, working experience with adults and migrants, updated on pedagogical and teaching methods, teacher training (from important competence)

- knowledge of different cultures, working experience with adults and migrants (from achieved competence)

All items are ranked higher by teachers and principals in adult education, which can be explained by the profile of the students they attract and the higher per- 
centage of distant learning. Finally, regarding age and preference or development of competence, no statistically significant relationship was found $\left(\mathrm{R}^{2}\right.$ varied from 0.01 to 0.024$)$.

\section{Comparing teachers and principals}

Comparing the two groups there are significant differences concerning their assessment of the importance of competence. Before moving to the differences, it is interesting to refer to the points of agreement. Both teachers and principals have reported good communication with students, assessing students' skills and knowledge, and creating conditions for learning as the three most important competencies. Concerning the least important competencies, principals rated the experience of working with adults last, a little bit higher than the experience of working with migrants. Working with recruitment and school marketing was ranked three positions before the end. Finally, both teachers and principals placed previous teaching experience very low in the importance scale with very little and non-statistical significance difference between them.

From the above-mentioned competencies, the statistical analysis shows significant differences between principals and teachers only for the experience of working with adults and working with recruitment and school marketing. The Mann Whitney Test indicated that the principals' mean ranking was higher than the teachers' with regards to recruitment and school marketing (mean rank principals $=205$, mean rank teachers $=179, \mathrm{p}<0.05$ ), while for experience of working with adults, teachers considered it more important (mean rank teachers $=193$, mean rank principals $=162$, $\mathrm{p}<0.05)$.

Concerning points of disagreement, principals rated the items working with recruitment and school marketing, be in agreement with the school's values and goals, knowledge of the curricula higher than teachers. The difference was statistically significant $(\mathrm{p}<0.05)$ and meaningful, since all these competencies are related to the working life and the function of the school; hence the fact that principals consider them more important is expected.

\section{Challenges}

Data on challenges in the teaching profession were collected only by teachers on a scale of 1 to 7 , with 1 labelled as the challenge affects me to some extent, 4 to a relatively large extent and 7 to a very large extent.

The challenges that affected teachers' work (Table 4) to the highest extent were students that need extra support, limited budget for competence development and high workload. These were followed by poorly motivated students and administrative work. 
Important and achieved competence for Swedish vocational teachers

Table 4. Mean ranks of challenges $(n=280)$.

\begin{tabular}{|c|c|c|}
\hline & Challenge & $\begin{array}{l}\text { Mean } \\
\text { Rank }\end{array}$ \\
\hline 1 & students who require extra support in teaching & 24.16 \\
\hline 2 & limited budget for competence development & 19.90 \\
\hline 3 & high workload (poor balance between work and leisure) & 19.81 \\
\hline 4 & poorly motivated students & 19.75 \\
\hline 5 & administrative work & 18.18 \\
\hline 6 & being a victim of one's sense of duty & 17.90 \\
\hline 7 & individualised teaching & 17.87 \\
\hline 8 & finding placement positions with guaranteed quality & 17.72 \\
\hline 9 & $\begin{array}{l}\text { lack of support in dealing with students with special } \\
\text { educational needs }\end{array}$ & 17.18 \\
\hline 10 & $\begin{array}{l}\text { keeping professional knowledge up to date } \\
\text { (within the basic profession) }\end{array}$ & 16.80 \\
\hline 11 & communication with placement environment for students & 16.68 \\
\hline 12 & teach students critical thinking & 16.65 \\
\hline 13 & language problems (students with weak Swedish) & 16.50 \\
\hline 14 & digitisation of teaching & 15.16 \\
\hline 15 & complex teaching content & 14.99 \\
\hline 16 & heterogeneous student groups & 14.48 \\
\hline 17 & $\begin{array}{l}\text { low status of vocational training and teachers } \\
\text { (e.g., low pay, low social recognition) }\end{array}$ & 14.42 \\
\hline 18 & lack of support from school management & 14.40 \\
\hline 19 & recurring curriculum reforms & 14.26 \\
\hline 20 & $\begin{array}{l}\text { management's demand for students' rapid knowledge } \\
\text { acquisition instead of deep learning }\end{array}$ & 13.99 \\
\hline 21 & classroom management & 13.99 \\
\hline 22 & developing teaching on sustainable development & 13.84 \\
\hline 23 & lack of support from students' families & 13.69 \\
\hline 24 & relationship with colleagues & 13.36 \\
\hline 25 & $\begin{array}{l}\text { prevention of discrimination and other abusive treatment } \\
\text { in the school }\end{array}$ & 12.43 \\
\hline 26 & fear of being judged as a bad teacher & 12.25 \\
\hline 27 & $\begin{array}{l}\text { balance between the professional identity and } \\
\text { the teacher identity }\end{array}$ & 11.57 \\
\hline 28 & lack of order in school (including bullying) & 11.27 \\
\hline 29 & students drop outs & 11.18 \\
\hline 30 & not having enough freedom at work & 10.62 \\
\hline
\end{tabular}


Concerning gender, Mann Whitney test between female $(\mathrm{N}=141)$ and male $(\mathrm{N}=137)$ participants was performed with regards to challenges, showing differences on students who need extra support $(\mathrm{U}=778, \mathrm{p}<0.05)$, finding placement positions with guaranteed quality $(\mathrm{U}=110, \mathrm{p}<0.05)$, fear to be seen as a bad teacher $(\mathrm{U}=$ $817, \mathrm{p}<0.05)$, administrative work $(\mathrm{U}=111, \mathrm{p}<0.05)$, individualised teaching $(\mathrm{U}=832$, $\mathrm{p}<0.05)$ and lack of support from students families $(\mathrm{U}=121, \mathrm{p}<0.05)$. Women evaluated students who need extra support, fear to be seen as a bad teacher and individualised teaching higher, meaning they affect them more in their work. Men rated higher the rest of the items mentioned above.

\section{Discussion}

The study aims at describing and exploring competencies that vocational teachers and principals perceived as important and achieved in relation to the challenges encountered at the workplace. The results indicate an agreement between teachers and principals on the most and least important competencies. The former were good communication with students, assessing students' skills and knowledge, and creating conditions for learning and the latter were previous teaching experience, working experience with adults and migrants and the competency related to recruitment of students and marketing of the school respectively.

Good communication with the students is approached as the most important and the most developed competence for vocational teachers in Sweden. Teachers perceived it as vital and, hence, worked towards its development. Communication is considered a generic competence (Pumphrey \& Slater, 2002), since it does not relate solely to the teaching profession (Langelotz, 2014), but to a number of other jobs and everyday activities. This competency ranked as the second most important in the study of Sartori et al. (2015), hence high in the ranking of importance. Mårtensson et al. (2019, pp. 92-93) state that 'the ability to build relationships with students is vital for all categories of teacher', as these relationships have a key role in learning. Hence, through teacher-student communication and interaction, the teacher can construct solid knowledge about the student (Köpsén, 2014), which is necessary for the teacher's role as the coordinator of the student's work-based learning process (Mårtensson et al., 2019). The question raised about good communication is: How is it acquired? It can be assumed that since this type of communication is targeted to students, it can only be developed through longer working experience, when teachers interact with students. Nevertheless, the item of previous teaching experience came very low in the ranking, among the five least important competencies, leading to contrasting findings. In that case, processes of boundaries crossing provide a potential explanation, with teachers bringing in the teaching profession communication and/or interpersonal compe- 
tence developed in the previous job or in another setting. In any case, the boosting of communication and interpersonal competence should be further supported by pre- and in-service teacher training.

Interesting is the low rating of working with migrant and adult students. While the case of adults can be explained by the low representation of adult education centres in the sample, statistics on migrant students show that in VET, they constitute $23 \%$ of upper secondary students (NAE, 2021a) and $55 \%$ of adults attending upper secondary vocational courses (NAE, 2019). This percentages refers only to those born outside Sweden (NAE, 2020e), meaning that second generation migrants are not included. Nevertheless, the respondents rated knowledge of different cultures as of medium importance. Knowledge of different cultures can be seen as a competence preparing teachers to work with migrants. In that case the knowledge is more important than the experience. At the same time how is this knowledge to be achieved if not through experience, since experience can expose the teachers to students with different cultures (often migrant students)? An alternative explanation is that while migrant students are part of the student population, the teachers do not consider it a factor of differentiating their teaching.

In addition, Teräs et al. (2019) reported that the skill of global connections was the least developed in Swedish vocational teacher training and the least applied in teaching. Connecting this underdevelopment to the general identification of lack of intercultural and multicultural competence in teachers (Dervin et al., 2020; Lehman 2017; Teräs \& Lasonen, 2013), this study's findings confirm previous research. Nevertheless, the high percentage of migrant students, indicates an urgent need to reconsider the enhancement of all competencies related to multiculturalism.

Keeping up to date vocational knowledge and having connections with their previous occupational environment seems to be among the important competencies based on previous studies (CSE, 2020; GOS, 2008; Manley \& Zinser, 2012; Mårtensson et al., 2019; Tapani \& Salonen, 2019). Fejes and Köpsén (2014) stressed the importance of maintaining participation in different occupational communities of practice as a way to enhance preparedness for teaching vocational subjects. The importance of this connection is stressed by actors with different perspectives, like the NAE and the CSE (2020). Nevertheless, in Sweden, the professional development of teachers is not regulated regarding the content and it is limited with reference to the initial occupation (Andersson et al., 2018; Fejes \& Köpsén, 2014). It often happens on teachers' own initiative, especially with reference to their vocational knowledge and skills (Andersson \& Köpsén, 2019). The limited budget for professional development, reported as the second bigger challenge by vocational teachers in this study, indicates that the conditions under which professional development occurs are blurry. As Vähäsantanen et al. (2009) suggest, individual learning initiatives should not take place outside 
working hours, and should be reinforced with resources to avoid the risk of personal contributions. Expecting vocational teachers to maintain up to date competence in two professions simultaneously is a demanding request that needs to be supported by all the actors included in VET (Köpsén \& Andersson, 2017).

Teacher training has a relatively low position in the ranking and previous teaching experience is placed even lower. Formal teaching qualifications in that case are not prioritised, even if they are included in the formal requirements for employment. The NAE has shown a tendency to make qualifications obligatory, with aim to quality assurance (Cedefop, 2020). At the same time, the reform of 2011 emphasised work-based learning and employability, demanding from vocational teachers to maintain their vocational identity updated (Ministry of Education, 2009). Köpsén and Andersson (2017) claimed that although the policy aimed to enhance the quality of VET, formal teaching qualifications and teaching competence were viewed as complementary. In addition, they stated that 'the current policy of vocational education primarily emphasises the teachers' vocational competence' (Köpsén \& Andersson, 2017, p. 70).

This policy seems to bring contradicting outcomes. The actual players of the education game, teachers and principals, seem to not perceive teacher training and, thus, formal qualifications as important as other competence. This can lead to conclusions as for the way competence is developed, and the idea that competence acquired through teacher training is either not sufficient, not relevant or it can be developed in the workplace. The reasons for the perceived low importance of formal competence should be further explored with a qualitative approach that would allow more depth.

Finally, comparing important and acquired competence, it seems like there is a variation between the need for improvement among different competencies. Competencies higher in the ranking present importance values higher than achievement values, meaning that there is a need for further development. Competencies in lower positions, however, have the opposite results with achievement values higher than the importance values. A possible explanation to this variation is that teachers obtain competencies not crucial for their job. Nevertheless, since these competencies are developed, it can be assumed that relevant tasks constitute part of teachers' everyday working life, but they are not so important. That is confirmed by the findings from challenges, where administrative work is reported as the sixth challenge influencing teachers' work. The statistically significant difference between important and achieved competence also raises questions about the role of vocational teacher education, and how it supports teachers in their job.

In addition, the change of pattern from higher to lower ranked competencies indicates that the selection of items was appropriate, as a more uniform pattern could be interpreted as a tool problem (Sartori et al., 2015). In any case, as Sartori et al. (2015) concluded, trusting only the questionnaire results can be misleading. 
In their study, the focus group interviews brought up results not in agreement with the questionnaire results, indicating the need for triangulation, especially in research on needs analysis.

Although a qualitative element seems to be necessary, in order to understand the reasons behind the results from the questionnaire, this quantitative approach has offered the possibility of attracting teachers' and principals' attention to competencies that would otherwise not be aware of. The inclusion of different actors has been crucial in avoiding self-perception and self-reported competence, while also supporting in identifying the agreement and disagreement areas between them with considerable impact in competence development. Additional actors whose view can contribute in this discussion are students and employers, as well as policy makers and the respective authorities. Clarifying the importance of competencies on a larger scale has created the basis for future research.

\section{Conclusion}

Drawing the broader picture of vocational teachers, this study has shown that the communication competence is seen as core in the teaching profession, while teacher training and experience with migrant students are not perceived as important in the context of Sweden. The mapping of competence does not only support a better understanding of what teachers and principals believe, but can also initiate a dialogue within VET actors on where vocational teacher training and development should be steered towards. This study can act as a starting point of discussion and reflection for both higher education institutions, offering vocational teacher training, and for regional and national policy and decision-making regarding recruiting and developing vocational teachers in Sweden.

\section{Endnotes}

${ }^{1}$ Göteborgs universitet, Högskolan Dalarna, Högskolan Kristianstad, Högskolan Väst, Karlstads universitet, Linköpings universitet, Linnéuniversitetet, Malmö universitet, Stockholms universitet, Umeå universitet

2 The options other had only three answers that were excluded.

${ }^{3}$ Kruskal Wallis was used instead of Mann Whitney because more than two types of schools were included. In the option other 5 schools were labelled as both high schools and adult education and 3 cases of schools labelled as both adult education and vocational college. 


\section{Notes on contributors}

Sofia Antera is a PhD candidate in the Department of Education, Stockholm University, Sweden. Her research interests focus on vocational education and training (VET), teacher training, professional competence development and adult education.

Marianne Teräs works as Professor of Education, in the Department of Education, Stockholm University. Her research mainly focuses on vocational and professional learning, immigration and interculturality. She is currently leading a research project called 'Integration and inclusion of migrants in and through vocation and work'.

Staffan Nilsson is an Associate Professor in Education, in the Department of Education, Stockholm University. His main research interests focus on professionalisation, professional competence, and the relationship among education, learning and work.

Helena Rehn is a Senior Lecturer in the Department of Education, Stockholm University. Her research mainly focuses on conceptions of important vocational knowledge and the construction of vocational identities. 


\section{References}

Alexiadou, N., \& Lundahl, L. (2016). Reforming Swedish education by introduction of quasi-markets and competition. In H. Gunter, E. Grimaldi, D. Hall, \& R. Serpieri, (Eds), New public management and the reform of education: European lessons for policy and practice (pp. 66-80). Routledge.

Andersson, P. Hellgren, M., \& Köpsén, S. (2018). Factors influencing the value of CPD activities among VET teachers. International Journal for Research in Vocational Education and Training, 5(2), 140-164.

https://doi.org/10.13152/IJRVET.5.2.4

Andersson, P., \& Köpsén, S. (2019). VET teachers between school and working life: Boundary processes enabling continuing professional development. Journal of Education and Work, 32(6-7), 537-551.

https:// doi.org/10.1080/13639080.2019.1673888

Antera, S. (2020). Adult educators' competences. The principals' view: A comparative study of Komvux and Folk high schools in Sweden. In L. Moreno Herrera, M. Teräs, \& P. Gougoulakis (Eds.), Teaching, learning and teacher: Emerging issues in research on vocational education and training, Vol. 5 (pp. 329-360). Premiss.

Antera, S. (2021). Professional competence of vocational teachers: A conceptual review. Vocations and Learning, 14(3), 459-479.

https://doi.org/10.1007/s12186-021-09271-7

Asghari, H. (2018). Defining professional skills from teachers' life stories. In L. Moreno Herrera, P. Gougoulakis, \& M. Teräs, (Eds), Voices from cross-national research: Emergent issues in vocational education \& training, Vol. 1 (pp. 23-59). Premiss.

Asghari, H., \& Berglund, I. (2020). Svensk yrkeslärarutbildning efter reformen 2011: Lärarstudenters uppfattningar om antagning, VFU och läraranställning. Nordic Journal of Vocational Education and Training, 10(2), 21-43.

https://doi.org/10.3384/njvet.2242-458x.2010221

Bound, H. (2011). Vocational education and training teacher professional development: Tensions and context. Studies in Continuing Education, 33(2), 107-119. https:// doi.org/10.1080/0158037X.2011.554176

Cedefop. (2020). Vocational education and training in Europe, 1995-2035: Scenarios for European vocational education and training in the 21st century. Cedefop reference series, No 114. Publications Office of the European Union. http:// data.europa.eu/doi/10.2801/794471

Cohen, J. (1988). Statistical power analysis for the behavioural sciences (2nd ed.). Academic Press.

Cohen, L., Manion, L., \& Morrison, K. (2011). Research methods in education (7th ed.) Routledge. 
Confederation of Swedish Enterprises (Svenskt Näringsliv). (2020). Utbildning av yrkeslärare i Sverige: Hur kan alla yrkeslärare bli behöriga? [Education for vocational teachers in Sweden: How can all vocational teachers become qualified?]. https:/ / www.svensktnaringsliv.se/bilder_och_dokument/lfccs4_hur-kanalla-yrkeslarare-bli-behorigapdf_1005110.html/Hur+kan+alla+yrkeslrare+bli+behriga\%253F.pdf

Dervin, F., Moloney, R., \& Simpson, A. (2020). Intercultural competence in the work of teachers: Confronting ideologies and practices. Routledge.

Evetts, J. (2014). The Concept of professionalism: Professional work, professional practice and learning. In S. Billett, C. Harteis, \& H. Gruber (Eds.), International handbook of research in professional and practice-based learning (pp. 29-56). Springer Science+Business Media.

https:/ / doi.org/10.1007/978-94-017-8902-8_2

Fejes, A., \& Köpsén, S. (2014). Vocational teachers' identity formation through boundary crossing. Journal of Education and Work, 27(3), 265-283. https:/ / doi.org/10.1080/13639080.2012.742181

Field, A. P. (2009). Discovering statistics using SPSS: (and sex and drugs and rock ' $n$ ' roll). SAGE Publications.

Government Offices of Sweden. (2008). Yrkeskunnande: En likvärdig sökväg till lärarutbildningen mot yrkesämnen [Vocational skills: An equivalent path to teacher education towards vocational subjects], Statens offentliga utredningar (SOU) [Swedish Government Official Reports], SOU 2008:112. https:/ / www.regeringen.se/rattsliga-dokument/statens-offentliga-utredningar/2008/12/sou-2008112/

Grollman, P. (2009). Professionalization of VET teachers and lecturers and practices in TVET institutions in an international perspective. In R. Maclean, \& D. Wilson (Eds.), International handbook of education for the changing world of work (pp. 1185-1201). Springer Science+Business Media.

https:/ / doi.org/10.1007/978-1-4020-5281-1

Harju, V., Pehkonen, L., Niemi, H., \& Niu, J. (2020). Ammatillisissa opettajakorkeakouluissa opettajaksi opiskelevien kokemuksia digitaitojen osaamisesta ja opiskelusta [Experiences of students studying to become teachers at polytechnics in digital skills]. Ammattikasvatuksen aikakauskirja, 22(1), 26-42. https://journal.fi/akakk/article/view/91031

Jarl, M., Fredriksson, A., \& Persson, S. (2012). New public management in public education: A catalyst for the professionalization of Swedish school principals. Public Administration, 90(2), 429-444.

https:/ / doi.org/10.1111/j.1467-9299.2011.01995.x

Kilbrink, N., Bjurulf, V., Olin-Scheller, C., \& Tengberg, M. (2014) Experiences of educational content in Swedish technical vocational education: Examples from the energy and industry programmes. International Journal of Training Research, 12(2), 122-131. https:/ / doi.org/10.1080/14480220.2014.11082035 
Köpsén, S. (2014). How vocational teachers describe their vocational teacher identity. Journal of Vocational Education E Training, 66(2), 194-211. https:/ / doi.org/10.1080/13636820.2014.894554

Köpsén, S., \& Andersson, P. (2017) Reformation of VET and demands on teachers' subject knowledge: Swedish vocational teachers' recurrent participation in a national CPD initiative. Journal of Education and Work, 30(1), 69-83. https:/ / doi.org/10.1080/13639080.2015.1119259

Köpsén, S., \& Andersson, P. (2018). Boundary processes in connection with students' workplace learning: Potentials for VET teachers' continuing professional development. Nordic Journal of Vocational Education and Training, 8(1), 58-75. https:/ / doi.org/10.3384/njvet.2242-458X.188158

Langelotz, L. (2014). Vad gör en skicklig lärare? En studie om kollegial handledning som utvecklingspraktik [What 'make(s)' a good teacher? A study of peer group mentoring as a practice of professional development]. [PhD thesis, Göteborgs universitet].

Lehman, C. L. (2017). Multicultural competence: A literature review supporting focused training for preservice teachers teaching diverse students. Journal of Education and Practice, 8(10), 109-116.

Manley, R. A., \& Zinser, R. (2012). A Delphi study to update CTE teacher competencies. Education \& Training, 54(6), 488-503.

https:/ / doi.org/10.1108/00400911211254271

Mulder, M. (2014). Conceptions of professional competence. In S. Billett, C. Harteis, \& H. Gruber (Eds), International handbook of research in professional and practice-based learning (pp. 107-137). Springer. https:/ / doi.org/10.1007/978-94-017-8902-8_5

Mårtensson, Å., Andersson, P., \& Nyström, S. (2019). A recruiter, a matchmaker, a firefighter: Swedish vocational teachers' relational work. Nordic Journal of Vocational Education and Training, 9(1), 89-110.

https:/ / doi.org/10.3384/njvet.2242-458x.199189

Ministry of Education. (2009). Högre krav och kvalitet $i$ den nya gymnasieskolan [Higher demands and quality of the new upper secondary school] (Prop. 2008/09:199). Ministry of Education.

NAE (Skolverket). (2014). Yrkeslärare per program [Vocational teacher per programme] (Rapport 414:2014). https:/ / www.skolverket.se/download/18.6bfaca41169863e6a65b2c8/1553965814233/pdf3319.pdf

NAE. (2019). Antal elever som under ett kalenderår läst minst 400 poäng yrkeskurser mot en inriktning motsvarande gymnasieskolans program, 2017-2019 [Number of students who during a calendar year read at least 400 credits of vocational courses towards a specialisation corresponding to the upper secondary school program, 2017-2019] (Tabell 8). https://www.skolverket.se/skolutveck- 
ling/statistik/sok-statistik-om-forskola-skola-och-vuxenutbildning?sok=SokC\&verkform=Komvux\&omrade $=$ Elever $\% 20 \mathrm{och} \%$ 20kursdeltagare\&lasar $=2019 \&$ run $=1$

NAE, ReferNet Sweden. (2019). Vocational education and training in Europe: Sweden (Cedefop ReferNet VET in Europe reports 2018). http:/ /libserver.cedefop.europa.eu/vetelib/2019/Vocational_Education_Training_Europe_Sweden_2018_Cedefop_ReferNet.pdf

NAE. (2020a). Anställda med lärarlegitimation med behörighet i ämne (exklusive introduktionsprogram) läsåret 2019/20 [Employees with a teacher qualification with eligibility in the subject (excluding introductory programmes) in the academic year 2019/20] (Tabell 8A). https:/ / www.skolverket.se/skolutveckling/statistik/sok-statistik-om-forskola-skola-och-vuxenutbildning?sok=SokC\&verkform $=$ Gymnasieskolan\&omrade=Personal\&lasar=2019/20\&run=1

NAE. (2020b). Lärare i olika lärarkategorier, läsåret 2019/20 [Teachers in different teacher categories, academic year 2019/20] (Tabell 5A). https:/ / www.skolverket.se/skolutveckling/statistik/sok-statistik-om-forskola-skola-och-vuxenutbildning?sok=SokC\&verkform=Gymnasieskolan\&omrade=Personal\&lasar $=2019 / 20 \&$ run $=1$

NAE. (2020c). Lärare i olika lärarkategorier, läsåret 2019/20 [Teachers in different teacher categories, academic year 2019/20] (Tabell 5A). https:/ / www.skolverket.se/skolutveckling/statistik/sok-statistik-om-forskola-skola-och-vuxenutbildning?sok=SokC\&verkform=Komvux\&omrade $=$ Personal\&lasar $=2019 / 20 \&$ run $=1$

NAE. (2020d). Skoladresser frain skolenhetsregistret [School addresses from the school register]. https://www.skolverket.se/skolutveckling/statistik/skoladresser-fran-skolenhetsregistret

NAE. (2020e). Lärarlegitimation och förskollärarlegitimation > Regler och krav för lärarlegitimation > Lärar- och förskollärarlegitimation och krav för att få anställning [Teacher qualification and pre-school teacher qualification $>$ Rules and requirements for teacher qualification> Teacher and pre-school teacher qualification and requirements for obtaining employment]. https:/ / www.skolverket.se/regler-och-ansvar/lararlegitimation-och-forskollararlegitimation/regler-och-krav-for-lararlegitimation/larar--och-forskollararlegitimation-och-krav-for-att-fa-anstallning

NAE. (2021a). Gymnasieskolan elevstatistik [Upper secondary school student statistics]. https:/ / siris.skolverket.se/reports/rwservlet?cmdkey=common\&geo=1\&report=gy_elever\&p_ar=2020\&p_lankod=\&p_kommunkod=\&p_skolkod=\&p_hmantyp $=\& p \_h m a n k o d=\& p \_f l i k=G \& p \_s u b=1$

NAE. (2021b). Pedagogisk personal i skola och vuxenutbildning läsåret 2020/21 [Educational staff in school and adult education academic year 2020/21] (Beskrivande statistik, 2021:433). https:/ / www.skolverket.se/getFile?file=7908 
Norberg, K. (2019). The Swedish national principal training programme: A programme in constant change. Journal of Educational Administration $\mathcal{E}$ History, 51(1), 5-14. https://doi.org/10.1080/00220620.2018.1513912

Nylund, M., \& Gudmundson, B. (2017). Lärare eller hantverkare? Om betydelsen av yrkeslärares yrkesidentifikation för vad de värderar som viktig kunskap på Bygg- och anläggningsprogrammet [Teacher or craftsman? The importance of vocational teachers' professional identification for what they regard as important knowledge in the Building and Construction programme]. Nordic Journal of Vocational Education and Training, 7(1), 64-87.

https:/ / doi.org/ 10.3384/njvet.2242-458X.177164

Pumphrey, J., \& Slater, J. (2002). An assessment of generic skills needs. Skills dialogues: Listening to employers. A comprehensive summary of generic skills requirements. Department for Education and Skills.

https:/ / dera.ioe.ac.uk/4698/1/SD13_Generic.pdf

Raudasoja, A., \& Kaitala, P. (2019). Ammatillisen koulutuksen opettajan osaamisvaatimukset [Competence demands of vocational education teachers]. HAMK Unlimited Journal, 22/11/2019.

https:/ / unlimited.hamk.fi/ammatillinen-osaaminen-ja-opetus/ammatillisen-koulutuksen-opettajan-osaamisvaatimukset

SACO. (2021). Skolledare: Information om lön, utbildning och arbetsmarknad [School leader: Information about salary, education and labour market] https:/ / www.saco.se/studieval/yrken-a-o/skolledare/

Salkind, N. J. (2010). Stratified sampling. In N. J. Salkind (Eds.), Encyclopedia of research design, Vol. 1, (pp. 1452-1454). SAGE Publications.

https:/ / doi.org/10.4135/9781412961288.n445

Sartori, R., Tacconi, G., \& Caputo, B. (2015). Competence-based analysis of needs in VET teachers and trainers: An Italian experience. European Journal of Training and Development, 39(1), 22-42. https:/ / doi.org/10.1108/EJTD-09-2013-0089

Stockholm University. (2020a). Processing of personal data - Stockholm University. https://pp-prod-admin.it.su.se/preview/www/2.153/2.213/2.39204/2.55859/2.55872

Stockholm University. (2020b). Utbildningsplan för Yrkeslärarprogrammet [Curriculum for vocational teacher programme].

https:/ / www.edu.su.se/polopoly_fs/1.314379.1483522839!/menu/standard/file/Utbildningsplan\%20vt17.pdf

Swedish Parliament. (2010). Education Act. https:/ / www.riksdagen.se/sv/Dokument0-Lagar/Lagar/Svenskforfattningssamling/Skollag-2010800_sfs-2010-800/

Swedish Research Council. (2017). Good research practice. Vetenskapsrådet.

Tapani, A., \& Salonen, A. O. (2019). Identifying teachers' competencies in Finnish vocational education. International Journal for Research in Vocational Education and Training, 6(3), 243-260. https:// doi.org/10.13152/IJRVET.6.3.3 
Teräs, M., Chang Rundgren, S. N., Eliasson, E., \& Ståhle, Y. (2019). Vocational teacher students' perceptions of 21st century skills in a vocational education programme in Sweden. In L. Moreno Herrera, M. Teräs, \& P. Gougoulakis (Eds.), Facets and aspects of research on vocational education and training at Stockholm University, Vol. 4. (pp. 394-426). Premiss.

Teräs, M., \& Lasonen, J. (2013). Developing vocational teachers' intercultural competence through a change laboratory method. Vocations and Learning, 6(1), 107-134. https:/ / doi.org/10.1007/s12186-012-9087-8

Tutlys, V., Gedvilienè, G., Saniter, A., Klein, I., Tacconi, G., \& Perrini, M. (2019). Development of teaching competences of VET teachers and trainers in Germany, Italy and Lithuania. In B. E. Stalder, \& C. Nägele (Eds.), Trends in vocational education and training research, Vol. II. Proceedings of the European Conference on Educational Research (ECER), Vocational Education and Training Network (VETNET) (pp. 397-404). https:/ / doi.org/10.5281/ zenodo.3371603

Vähäsantanen, K., Saarinen, J., \& Eteläpelto, A. (2009). Between school and working life: Vocational teachers' agency in boundary-crossing settings. International Journal of Educational Research, 48(6), 395-404. https:/ / doi.org/10.1016/j.ijer.2010.04.003

Wenström, S., Uusiautti, S., \& Määttä, K. (2018). 'The force that keeps you going': Enthusiasm in vocational education and training (VET) teachers' work. International Journal for Research in Vocational Education and Training, 5(4), 244-263. https:/ / doi.org/10.13152/ijrvet.5.4.1 